\title{
P 329
}

\section{香川県の娥域における高龄者の健康問題に関する模討 その 2}

○忠津佐和代 ${ }^{11}$, 武田則昭 ${ }^{2}$, 小倉永子 ${ }^{21}$, 田芹昌也 ${ }^{21}$, 三宅康弘 ${ }^{21}$, 藤井智恵子 ${ }^{31}$, 荕谷小夜子" ${ }^{4}$, 實成文彦 ${ }^{2}$,

香川医科大学 看愎学科

四国電力中央健康管理センター

[はじめに] 最近の労働省による労働人口推計では、平成 12 年 $(2000$ 年) の 60 歳以上労㗢人口は 880 万人、しかも 70 藏にてなお就労を希望するものが、42\%に達するといわ れている。一方、職域における高齢者の健康保持・増進に 関する取り組みは、地域保健行政に比較すると低迷してお り、㗢き盛りの青壮年労㗢者に力点が置かれている現状が ある。しかしながら、少産少死の中、高齡者に就労が求め られることになり、特に中小規模事業所においてその要請 が高くなることが予測される。そのため、産業保健現場に おいても、事業所における高齢化問題をどのように捉え、 そのための対策をどのように計画し、活動・評価していく かが重要になると思われる。そこで今回、報告者らは香川 県下の從業員数 50 人以上の事業所を中心に高齢化問題に ついて調査・検討したので、その概要について報告する。

[対筑及ひ方法等］調査は平成 9年 1 月 10 日〜 31 日の間 に行った。香川県下の従業員数 50 人以上の全 853 事業所 に郵送にて質問票を送付し、各事業所において記入後、283 事業所から返送された(回収率 $28.3 \%$ )。

[洁果と考策]「高秢者に対して何らかの対策」は、「すで に講じている」12.9\%、「今のところ講じていないが、今後 は考えていきたい」59.2\%、「今のところ講じておらず、今 後も予定がない」 $27.9 \%$ あった。

「高蛉者対策のうち主たる3つの事項」は、「現役就業中 の健康管理上の配虑」 $75.3 \%$ 、「現役就業中の就職上の配虑」 $42.8 \%$ 、「現役就業中の経済的配虑」 $33.2 \%$ の順で、以下「退 職後の健康管理上の配虑」退職後の経済的配虑」「退職後の 就賗上の配虑」「その他」の順であった。（図1）

「高榆者対策のうち一番重要と考えている事項」は、「現 役就業中の健康管理上の配虑」 $71.5 \%$ で最も多く、以下「現 役就業中の就職上の配慮」 $10.4 \%$ 、「現役就業中の経済的配 虑」 $7.2 \%$ 、「退職後の健隶管理上の配慮」 $3.6 \%$ 、「退職後の 释済的配虑」 $3.6 \%$ 、「退職後の就職上の配慮」 $3.2 \%$ 、「その 他」 $0.5 \%$ の順であった。

「高秢者の健康対策のうち主たる $5 つ$ 事項」は、「定期 健康診査」 $86.3 \%$ 、「健康診查結果に基づく本人に対する医 師による指導」 $66.4 \%$ 、「配置換え、仕事の軽減化、職場 睘境改善等の労務管理上の配虑」 $63.1 \%$ 、以、主たるも のは「健康診査結果に基づく本人に対する医師による日常 生活等保健指導」「健康づくり（T H P ) 等の教育、故発活動」 「心の健康づくり」「健康診査結果に基づく本人に対する保 健婦・看護婦による指導〕「健康診査結果に基づく家族ぐる みの医師による指導」健康診査結果に基づく家族ぐるみの
${ }^{2)}$ 香川医科大学人間㻴境医学講座得生・公衆得生学

4) (琍夕夕゙ノ安全得生課
「高龄者の健康対策のうち一番重要と考えている事項」 は、「定期健康診査」 $43.1 \%$ 、「健康診査結果に基づく本人 に対する医師による指導」 $14.7 \%$ 、「配置換え、仕事の軽 減化、職場環境改善等の労務管理上の配虑」13.8\%の順で あった。

総じて見ると、健康対策を重視してはいるが、健康概念 が定期健康診査でチェックできる範囲にとどまっている傾 向が示された。なお、健康診査関連事項を除くと、「配置 換え、仕事の軽娍化、職場䍗境改善等の労務管理上の配慮」 「健康づくり ( T H P ) 等の教育、啓発活動」という事項が、 多く選ばれており、「心の健康づくり」はやや低率であった。 なお、職場の健康対策は職場のみで解決できるものでは なく、家族も含め家族ぐるみの対応が重要と考えられるが、 「家族ぐるみの指導」は低率であった。

[まとめ] 高跉者対策は、いまだ十分ではなく、「定期健 康診査」が主たる健康対策で、職場の環境改善や心の問題 等に重点を置いている事業所は少なかった。
